\title{
A comparative analysis on ranking insurance firms using RBC and CAMELS
}

\author{
Zahra Houshmand Neghabi $^{\mathrm{a}^{*}}$, Sudabeh Morshedian Rafiee ${ }^{\mathrm{b}}$ and Zahra Soleymani ${ }^{\mathrm{c}}$
}

${ }^{a}$ Faculty member, Department of Commercial Management, Islamshahr Branch, Islamic Azad University (IAU), Iran

${ }^{b}$ Assist. Prof. \& Faculty Member, Department of Commercial Management, Islamshahr Branch, Islamic Azad University (IAU), Iran

${ }^{c}$ M.A. Student, Department of management, School of Management and Human Sciences, Tehran North Branch, Islamic Azad University (IAU), Tehran, Iran

\begin{tabular}{l}
\hline A R T I C L E I N F O \\
\hline Article history: \\
Received April 28, 2012 \\
Accepted 6 July 2012 \\
Available online \\
July 12 2012 \\
\hline Keywords: \\
Insurance \\
CAMELS \\
RBC \\
Ranking method
\end{tabular}

\begin{abstract}
A B S T R A C T
Ranking insurance firms plays an important role on choosing the most appropriate company for receiving appropriate services especially long term insurances such as life insurances. The proposed model of this paper uses two well-known methods of CAMELS and RBC to rank 18 active private and governmental insurance firms in Iran over the period of 2009-2011. The results of Spearman test imply that there is no meaningful difference between these two methods for year 2010 and year 2011 and according to Freedman test, there is not meaningful difference between these two methods in any three years of 2009, 2010 and 2011. In summary, we can conclude that the results of both methods could be used in practice.
\end{abstract}

\section{Introduction}

One of the most popular methods for ranking insurance firms is to assess financial strength of the firms. There are different techniques for assessing insurance companies such as CAMEL, RBC, etc. Altman (1984) proposed one of the most popular techniques for predicting the likelihood of failure for financial companies. In his method, he used different financial ratios extracted from balance sheet and statement of some bankrupted firms and using regression technique found the relationship between financial ratios and the likelihood of business failure. Ambrose and Seward (1988) proposed another method for the best's ratings financial ratios and prior probabilities in insolvency prediction. Ambrose and Carroll (1994) in another study proposed a method for using best's ratings in life insurer insolvency prediction. Browne and Hoyt (1995) discussed economic and market predictors of insolvencies in the property-liability insurance industry. Lee and Urrutia (1996) analyzed insolvency in the property-liability insurance industry by performing a comparison between Logit and hazard models. Grace et al. (1998) used a risk-based capital and solvency screening in propertyliability insurance.

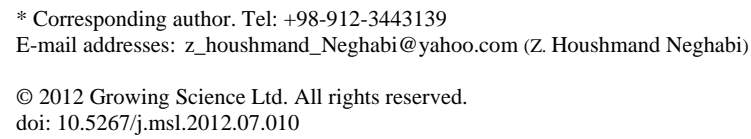


There are literally different works associated with credit scoring and financial risk based on CAMEL measure. Dincer et al. (2011) discussed the relative importance of crisis in November 2000 and February 2001, especially in terms of banking in Turkey. They also emphasized that despite the fact that there were a lot of works on the banking performance evaluation, CAMELS ratios which are one of the important analysis kinds for performance assessment in banking sector comprise necessary parameters reflecting results of banking sector performance. Hsiao and Whang (2009) evaluated the financial soundness by implementing CAMEL rating systems and the risk-based capital (RBC) models. They also explored whether insurers exit a substantial difference of financial stability or not between domestic and foreign branch life insurers. The study also focused on an efficient insolvency anticipation framework and explained that the artificial neural network performed better for classification than the traditional discriminant method since the artificial neural network's accurate discrimination rate of $95.2 \%$ with a lower Type I error of 0.0274 and Type II error of 0.0769 .

Curry et al. (2008) quantified the short-term and long-term effects of bank supervision based on CAMEL rating system on various categories of loan growth including commercial and industrial, consumer and real estate loans. They performed dynamic loan growth equations at the state-level augmented by the inclusion of CAMEL ratings for all banks in the state, after controlling for banking and economic circumstances. They performed these regressions for two distinct sub-periods where the first one was 1985-1993 and the second one was on 1994-2004. For the first period, 1985-1993, they reported that out of the three loan categories considered, business lending was the most sensitive to changes in CAMEL ratings, although the other loan categories also demonstrated some sensitivity. They found little evidence suggesting that the impacts of changes in any of the components of CAMEL ratings varied systematically from the impacts of changes in the composite CAMEL. For the second period, they reported little evidence that changes in CAMEL ratings had any systematic impact on loan growth for any of the loan categories considered.

Cooper (2009) studied regulation and corporate governance techniques at a sample of non-publicly traded state member banks in 2006 based on a simultaneous regression technique. Her results indicated that insider representation on the board had a positive impact on both director and executive compensation in commercial banks. Regulatory ratings, however, are only associated with bank performance - not to board structure or compensation schemes. This could be contributed to less insight asymmetry between managers and owners at private banks. In addition, directors could be highly rewarded for strong CAMELS ratings. She explained that the governance framework of private banks was not influenced by regulatory ratings; however, the percent of insiders on the board impacted actions of the board to a large extent.

Sahut and Mili (2011) investigated banking distress in MENA countries. They implemented a two-level nested logit model to construct a model between merger decisions and the distressed state of banks. They challenged the view that specific bank indicators such as CAMEL category and bank size are more important determinants of banking distress than macroeconomic variables. In fact, their empirical study indicated that $67 \%$ of the distressed banks in their sample were involved in merger transactions and that weak financial status systematically increased the possibility of a bank being involved in a merger. They concluded that global economic conditions do not substantially influence the decision of distressed banks to initiate a merger policy.

The primary objective of CAMELS ratings is to determine a bank's overall circumstances and to identify its strengths and weaknesses. It can be defined as an international bank-rating system where bank supervisory authorities' rate institutions based on six factors namely capital adequacy, asset quality, management quality, earnings, liquidity and sensitivity to market risk. Bank supervisory authorities normally give each bank a score on a scale of one for the best one to five for the worst item for each factor. According to this regulation, a bank is considers high quality institution when it receives an average score less than two and a bank with scores greater than three is considered to be less-than-satisfactory establishments. CAMELS system helps the supervisory authority detects banks that are in need of attention. National Credit Union Administration in October 1987 adopted the CAMEL Rating System. It was implemented as an internal tool to measure risk and allocate resources for supervision purposes and, to the best of our knowledge, the last version of CAMEL rating system was released in Letter to Credit Unions NO.161, dated December, 1994. This method makes an assessment based on the following considerations,

- Volume and nature of problem assets in association with total capital and necessary reserves,

- Balance sheet framework including off balance sheet items, market and concentration risk

- Nature of business activities and risks to the bank 
- Asset and capital growth experience and prospects

- Earnings past performance, future outlook and distribution of dividends

- Capital needs and compliance with regulatory requirements

- Access to capital markets and sources of capital

- Capability of management to handle these issue factors

When a capital receives number one rating, the capital levels and ratios go well above all regulatory requirements, it maintains strong earnings performance and well managed and controlled growth. As the rating declines from one to two, capital and solvency ratios exceed regulatory requirements buy there are some limitations on management ability to maintain sufficient capital to support risks. The ranking number 3 indicates that the bank complies with capital adequacy and solvency needs but it also has major weaknesses since it may have high level of problem assets in excess of $25 \%$ of total capital and it may also fail to comply with regulatory regulations. Capital ranking 4 states that the bank is experiencing severe problems, which are the results of insufficient capital to provide support risks related to business and operations. Finally, capital rating 5 indicates that the bank is insolvent and is likely end up with bankruptcy.

Risk-based capital (RBC) method is another technique for evaluating financial institutions such as banks and insurance firm. Avery and Berger (1991) analyzed RBC standards using data on U.S. banks from 1982 to 1989. The relationship between bank performance and the RBC relative risk weights and adaptability with the RBC standards were also evaluated. The results indicated that RBC constitutes a substantial improvement over the old capital standards, although both standards incorporated useful independent information. The results also revealed that relative to the old standards, the new standards were much more strict on some large banks and were more stringent overall. As a result, banks representing more than one-fourth of all bank assets would have failed the new standards as of 1989.

Grenadier and Hall (1996) explained that bank RBC standards need banks to hold differing amounts of capital for various classes of assets, based almost entirely on a credit risk criterion. They presented both a theoretical and empirical framework for evaluating such standards by presenting a model based on a pricing methodology for loans subject to default risk. The model indicated that the returns on such loans were influenced by the complicated interaction of the likelihood of default, the consequences of default, term structure variables, and the pricing of factor risks in the economy. They also found that the weights fail even in their limited objective of correctly quantifying credit risk. For instance, their findings specified that the RBC weights over-penalize home mortgages, which had an average credit loss of 13 basis points, relative to commercial and consumer loans. The RBC rules also contained a substantial bias against direct mortgages compared with mortgagebacked securities. They even found out that large differences in the credit riskiness of loans within the $100 \%$ weight class and potentially large benefits to loan diversification, neither of which are considered in the RBC regulations.

\section{Methodology}

The proposed study of this paper attempts to use two different ranking techniques to study the current status of insurance firms and also find out whether there is any meaningful difference between two ranking methods discussed earlier, RBC and CAMELS. For the proposed study of this paper, RBC factor is calculated based on the following formula,

$$
R B C=R_{0}+\sqrt{R_{1}^{2}+R_{2}^{2}+R_{3}^{2}+R_{4}^{2}+R_{5}^{2}},
$$

where $R_{0}$ has two parts of $R_{0}^{\prime}$ and $R_{0}^{\prime \prime}$, which represent inside and outside organization risk components, respectively. In addition, $R_{1}$ is associated with fixed income investment, $R_{2}$ is the risk associated with other investments, $R_{3}$ is the credit risk, $R_{4}$ is the risk of under provisioning and $R_{5}$ is under pricing risk, respectively. 
CAMEL technique uses the following method to measure TFI index,

$Y_{i}=\frac{X_{i}-X_{\min }}{X_{\max }-X_{\min }} \times 100$

$T F I=\sum_{i=1}^{n} W_{i} X_{i}$

where $X_{i}$ and $W_{i}$ are the financial ratios along with weights of these ratios, respectively.

The proposed study of this paper considers whether there is any meaningful difference between the risk computed by CALELS and RBC in insurance firms, which are actively operating in Iran. In other words, the null hypothesis specifies that the correlation ratio between these two components is zero ( $\beta=0)$ while the alternative hypothesis is that the ratio is not equal to zero $(\beta \neq 0)$. The Spearman ratio is calculated as follows,

$\beta=1-\frac{6 \sum_{i=1}^{n} d_{i}^{n}}{n\left(n^{2}-1\right)}$,

where $d$ is the rank and $n$ is the number of observation, i.e. number of insurance firms, respectively.

\section{The results}

In this section, we present details of the results of the implementation of Eq. (1) and Eqs. (2-3) to calculate the risks associated with 18 different banks. Table 1 demonstrates the results of our survey.

Table 1

The results of ranking of different 18 insurance firms

\begin{tabular}{ccccccc}
\hline & & CAMELS & & & RBC & \\
\cline { 2 - 7 } Insurance firm & 2009 & 2010 & 2011 & 2009 & 2010 & 2011 \\
\hline 1 & 2 & 15 & 3 & 3 & 3 & 3 \\
2 & 4 & 8 & 2 & 1 & 2 & 2 \\
3 & 9 & 10 & 5 & 4 & 4 & 4 \\
4 & 1 & 4 & 11 & 2 & 1 & 1 \\
5 & 17 & 7 & 16 & 16 & 10 & 6 \\
6 & 6 & 17 & 8 & 9 & 11 & 13 \\
7 & 16 & 1 & 6 & 15 & 16 & 5 \\
8 & 11 & 16 & 10 & 7 & 7 & 11 \\
9 & 7 & 12 & 1 & 5 & 5 & 7 \\
10 & 8 & 11 & 18 & 6 & 6 & 10 \\
11 & 12 & 18 & 9 & 12 & 13 & 16 \\
12 & 14 & 3 & 15 & 17 & 17 & 18 \\
13 & 5 & 6 & 7 & 10 & 9 & 12 \\
14 & 3 & 14 & 13 & 8 & 8 & 9 \\
15 & 10 & 9 & 17 & 11 & 15 & 14 \\
16 & 13 & 13 & 14 & 13 & 14 & 15 \\
17 & 15 & 5 & 4 & 14 & 12 & 8 \\
18 & & 2 & 12 & & 18 & 17 \\
\hline
\end{tabular}

\subsection{Spearman test}

We now examine whether there is any meaningful difference between two ranking methods using Spearman test. Table 2 shows details of our results, 
Table 2

The results of Spearman test

\begin{tabular}{lcl}
\hline Year & Spearman test & Sig \\
\hline CAMELS $_{2009 .}$ RBC $_{2009}$ & -.838 & .000 \\
CAMELS $_{2010 .}$ RBC $_{2010}$ & .298 & .229 \\
CAMELS $_{2011 .}$ RBC $_{2011}$ & -.507 & .321 \\
\hline
\end{tabular}

As we can see from the results of Table 2, when the level of significance is five percent, null hypothesis is rejected only during the year of 2009 but the null hypothesis cannot be rejected for year 2010 and 2011.

\subsection{Freedman test}

Next, we examine whether there is any meaningful difference between the results of two ranking system over the period of 2009-2011 for all 18 insurance firms. Table 3 shows the results our Freedman test.

\section{Table 3}

The results of Freedman test

\begin{tabular}{ccc}
\hline Year & Freedman test & Sig \\
\hline 2009 & .250 & .617 \\
2010 & .222 & .637 \\
2011 & .529 & .467 \\
\hline
\end{tabular}

As we can observe there is no meaningful difference between two ranking systems in any years from 2009 to 2011.

\section{Conclusion}

In this paper, we have presented an empirical study to measure the ranking of various insurance companies in Iran using two well-known ranking techniques of CAMELS and RBC. The proposed model uses the information for the fiscal year of 2009, 2010 and 2011. The purpose of this research was whether there was any meaningful difference between these two ranking methods. Therefore, we have used Spearman and Freedman tests to find the answer for these two questions. The results of Spearman test imply that there is no meaningful difference between these two methods for year 2010 and 2011 and according to Freedman test, there was not meaningful difference between these two methods in any three years of 2009, 2010 and 2011. In summary, we can conclude that the results of both methods could be used in practice.

\section{Acknowledgment}

The authors would like to thank the anonymous referees for their comments on earlier version of this work.

\section{References}

Altman, E. I. (1984). The success of business failure prediction models: An international survey. Journal of Banking and Finance. 8, 171-198.

Ambrose, J. M., \& Seward, J. A. (1988). Best's ratings financial ratios and prior probabilities in insolvency prediction. Journal of Risk and Insurance, 55, 229-244.

Ambrose, J. M., \& Carroll, A. M. (1994).Using best's ratings in life insurer insolvency prediction. Journal of Risk and Insurance, 61, 317-327.

Avery, R.B., \& Berger, A. N. (1991). Risk-based capital and deposit insurance reform. Journal of Banking \& Finance, 15(4-5). 847-874. 
Browne, M. J., \& Hoyt, R. E. (1995). Economic and market predictors of insolvencies in the property-liability insurance industry. Journal of Risk and Insurance, 62, 309-327.

Cooper, E.W. (2009). Monitoring and governance of private banks. The Quarterly Review of Economics and Finance, 49(2), 253-264.

Curry, T.J., Fissel, G.S., \& Ramirez, C.D. (2008). The impact of bank supervision on loan growth. The North American Journal of Economics and Finance, 19(2), 113-134

Dincer, H., Gencer, G., Orhan, N., \& Sahinbas, K. (2011). A Performance Evaluation of the Turkish Banking Sector after the Global Crisis via CAMELS Ratios. Procedia - Social and Behavioral Sciences, 24, 1530-1545.

Grace, M., Harrington, S., \& Klein, R. (1998). A risk-based capital and solvency screening in property-liability insurance: Hypotheses and empirical tests. Journal of Risk and Insurance, 65(2), 213-243.

Grenadier, S.R., \& Hall, B.J. (1996). Risk-based capital standards and the riskiness of bank portfolios: Credit and factor risks. Regional Science and Urban Economics, 26(3-4), 433-464.

Hsiao, S.H., \& Whang, T. J. (2009). A study of financial insolvency prediction model for life insurers. Expert Systems with Applications, 36(3), 6100-6107.

Lee, S. H., \& Urrutia, J. L. (1996). Analysis and prediction of insolvency in the property-liability insurance industry: A comparison of Logit and hazard models. Journal of Risk and Insurance, 63, 121-130.

Sahut, J.M., \& Mili, M. (2011). Banking distress in MENA countries and the role of mergers as a strategic policy to resolve distress. Economic Modelling, 28(1-2), 138-146 